\author{
Michael Gameli DZiwornu \\ University of Milan-Bicocca, Italy \\ TOMASZ RACHWAE \\ Pedagogical University of Cracow, Poland
}

\title{
The Trade Specificities between Turkey and Poland
}

\begin{abstract}
The general consensus among policymakers and researchers is that in order to increase economic growth, it is necessary to diversify trade. The objective of this paper, therefore, is to analyse the dynamics of trade, specifically the export concentration of products between Turkey and Poland from 1995 to 2015. Despite a historically complicated relationship, these two countries have significantly strengthened economic ties and political cooperation. The last two decades in particular, have witnessed the manifestations of such close cooperation between these two countries. By measuring the export product concentration using the Herfindahl-Hirschman Index (HHI), we found higher export concentration from Turkey to Poland in the majority of products traded, in contrast to Poland's exports to Turkey. The analysis carried out also indicates the imperative for the two countries to consolidate their existing partnership by removing trade barriers that may hinder stronger economic relation and cooperation. Furthermore, reforms are needed in both countries to closely align production structures necessary for greater and more sustained trade partnership.
\end{abstract}

Keywords: export; HHI; import; Poland; Turkey

Received: 7 December 2017

Accepted: 18 July 2018

Suggested citation:

Dziwornu, M.G, Rachwał, T. (2018). The Trade Specificities between Turkey and Poland. Prace Komisji Geografii Przemysłu Polskiego Towarzystwa Geograficznego [Studies of the Industrial Geography Commission of the Polish Geographical Society], 32(3), 201-215. https://doi.org/10.24917/20801653.323.13

\section{INTRODUCTION}

Despite a historically complicated relationship, Turkey and Poland have significantly strengthened economic ties and political cooperation. The earliest account of contact between the Turks and Poles dates back to the beginning of the 15th century when the Ottoman Turks, Poles, and Lithuanians established diplomatic relations (Topaktaş, 2014). In 1414, Polish King Władysław Jagiełło sent a delegation to Sultan Mehmed I, ruler of the Ottoman Empire, to establish diplomatic relations. Trade relations between the two countries formally commenced in the middle of the 15th century specifically in 1439 when a commercial agreement was signed. Subsequent bilateral agreements were advanced after the Second World War, as well as other noteworthy economic 
cooperation agreements in the 1970s and 1980s. Turkey was broadly instrumental in championing the unification of Poland expressed through the support of the Polish struggle for independence in the 19th century (Mierzwa, 2015). The nature of TurkishPolish relation is rightly captured by the leaders and industry players of both countries on the occasion of the Polish-Turkish Business Forum on the 8th of November 2013 in Warsaw, Poland. The leaders expressed a deep imperative for stronger cooperation in key sectors of their economies. During the forum Donald Tusk, the former Prime Minister of Poland, remarked that "For Poland, Turkey is an especially close and cordial partner for historical reasons, but above all on account of the future, which [...] belongs to us, Turks and Poles. Since 2004, our trade with Turkey has grown threefold - something that shows what great reserves lie dormant in our economies". His Turkish counterpart, Recep Tayyip Erdoğan, then Prime Minister of Turkey, also stated that "I think that the volume of trade between Poland and Turkey is insufficient. Five billion USD is a low sum in consideration of our two countries' potential. We want the trade volume to increase to 10 billion in the nearest future".

The Turkey-Poland relation goes beyond trade and investment and includes various educational and cultural cooperation. For instance, Poland is a popular destination for Turkish students within the European Union (EU) sponsored Erasmus exchange program. Turkish students constitute the largest group of exchange students in Polish universities as compared to other European universities (Balcer, 2015). The objective of this paper is to analyse the dynamics of trade, specifically the export concentration of products between Turkey and Poland from 1995 to 2015.

\section{LITERATURE REVIEW: ECONOMIC AND TRADE DYNAMICS BETWEEN TURKEY AND POLAND}

Turkey and Poland pursued rigorous trade liberalisation policies during the time of political and economic transition in the 1980s to facilitate an export-led growth model (Krueger and Aktan, 1992; Togan, 1994; Öniş and Rubin, 2003; Pamuk, 2007; Öniş and Bayram, 2010; Ergüzel et al., 2016). According to the World Bank (2016), Poland has the largest economy in Central Europe with a GDP of US\$ 534.3 billion (2015) and the 14th most attractive economy in the world for investment (ThinkTank Dossier, 2014). The economic fortunes of Poland were further boosted by its integration into the EU in 2004. Similarly, Turkey is a fast-growing emerging economy with a GDP of US\$721.1 billion (2015) (World Bank, 2016). Economic growth in both countries was affected by a wave of liberalisation and the global financial crisis. For instance, the share of export and import to GDP in Poland increased from 38\% in 1994 to 49\% in 1997, before falling to $44 \%$ in 1999 with manufacturing products accounting for most of the export share (WTO, 2000). In the same vein, Turkey experienced a relatively weak export share in the early 1990s compared to Poland. Relative Economic reforms in Turkey over the years increased performance and foreign trade valued at $\$ 299$ billion by the end of 2010 (Ustaoğlu and Yıldız 2011). In terms of market diversity, the Turkish economy has grown and become more diversified, increasingly exploring new markets for trade and investment (World Bank, 2014; Ergüzel et al., 2016). Despite attempts by Poland to diversify foreign trade to Asia, Africa, and Latin America, 80 percent of Polish exports finds its way into the European market. However, with regards to export sophistication, Emirhan (2008) found that Polish exports specifically manufacturing, were more 
Figure 1. Share of Export, Import and Trade Balance to GDP of Turkey and Poland

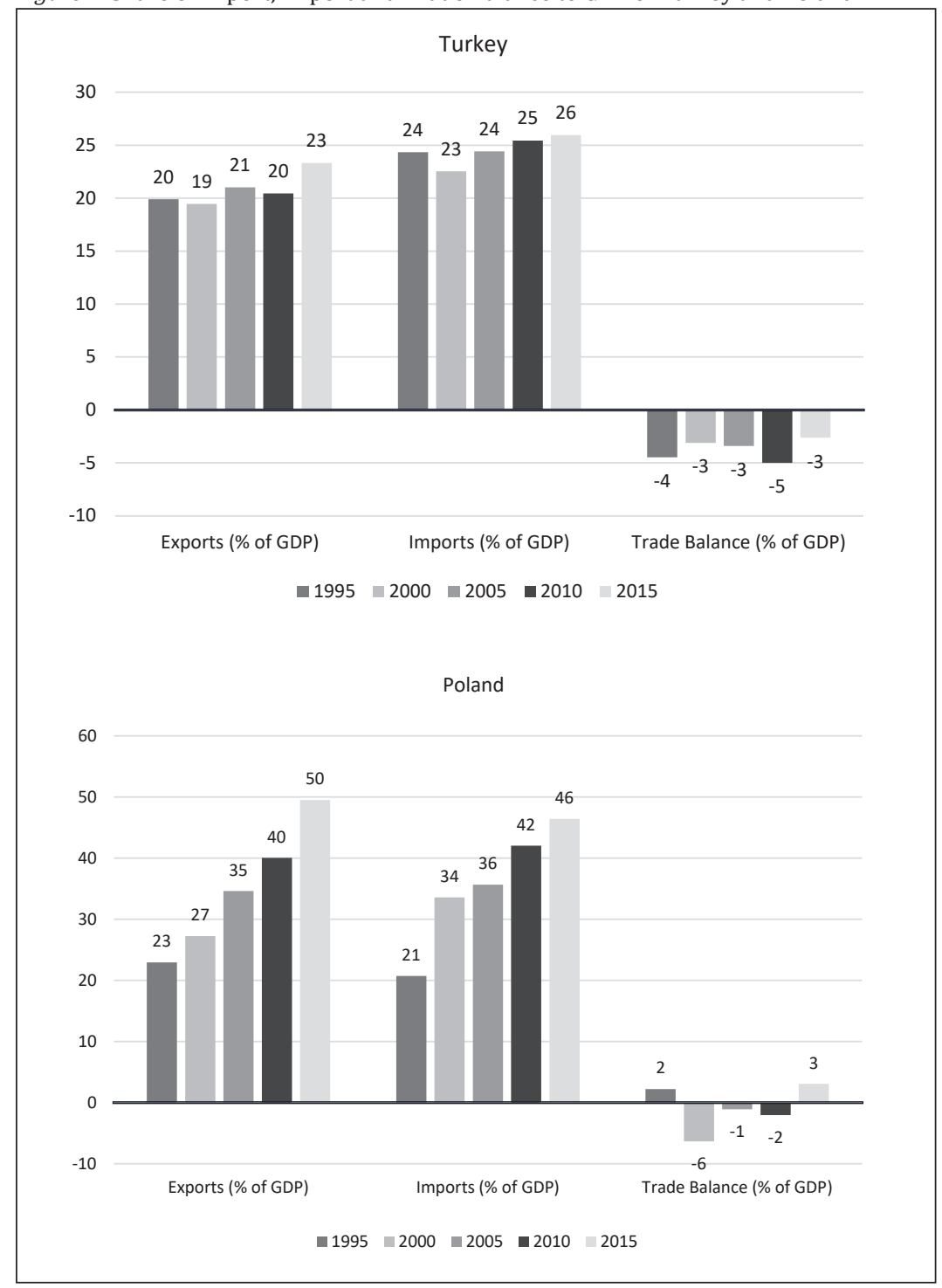

Source: WITS-UNSD Comtrade, World Development Indicators

sophisticated than Turkey by measuring 3 digits ISIC industries in the manufacturing sector.

Turkey's engagement with Poland can be perceived from the European Union perspective. Bilateral trade between Turkey and the EU, in general, has increased more than fourfold since 1996 (World Bank 2014), accounting for 56 percent of overall exchange in 1999. Despite the fact that trade relations dropped to 42 percent in 2009 (Kirişçi and Kaptanoğlu, 2011; Ergüzel et al., 2016), trade and investment between Turkey and the EU reached US\$ 147 billion in 2012 making Turkey the EU's sixth largest trading partner and the EU Turkey's biggest (Yilmaz, 2003; Seymen and Bilici, 2009; 
World Bank, 2014). Furthermore, investment-related reforms introduced in 2003, as well as privatisation programmes facilitated the flow of FDI to Turkey and improved the general investment climate (Demianova, 2008). The largest contributors to FDI from the EU to Turkey are the Netherlands, Austria, the UK, Luxembourg, Germany, and Spain, led by large manufacturing industries such as Bosch, Mercedes, and Toyota and agro-processing industries. Turkey's relations with the EU has also helped streamlined production structures and integrated Turkish companies in the wider production network to ensure the quality and sophistication of Turkey's exports (World Bank, 2014). Put differently, the implementation of the Customs Union between the EU and Turkey improved both exports and imports (Inançlı and Akal, 2013). A growing body of literature on comparative economics tend to focus on and argue for trade diversification. In essence, trade diversification is a key determinant of economic growth. For instance, Arip et al. (2010) found a higher correlation between export diversification and economic development in Malaysia between 1980 and 2007. Trade diversification also varies considerably in developed and developing countries. Studies conducted by Wilhelms (1967), Voinea (2002), Saif and Barakat (2005), Xin and Liu (2008), Hesse (2008), World Bank (2007), Ayranci (2009), Carrere et al. (2011), Naude and Rossouw (2008), using various indexes and measures concluded that trade diversification was higher in developed countries and much lower in developing countries, particularly in Africa and the Middle East. The literature on Turkey-Poland relation in general and economic and trade cooperation in particular are very limited. Considerable empirical analysis explicitly examining Turkey-Poland trade relations, export concentration, and diversification are generally explored from a wider Turkey-EU perspective (World Bank 2014; Erkan 2014; Gros and Selçuki 2013; Seymen 2009; Seymen and Bilici 2009; Secer 2008; Şimşek et al., 2007; Belke 2005; Yilmaz 2003; Gökalp and Yıldırım 2004; Erlat and Sahin 1998). Moreover, literature on Polish trade relations are largely oriented towards the EU and China (Gurgul and Lach, 2010; Maćkowiak, 2011; Parteka, 2013). This may be partly due to the limited political and economic engagements between the two countries. This paper looks at the dynamics of trade between two non-traditional trading partners. Specifically, this study examines the inherent sectoral compositions and structural changes in Terms of Trade, as well as the export concentration of products between the two countries. This study is significant as it seeks to identify areas and sectors where much economic and trade cooperation can be advanced.

\section{Methodology}

The study utilises the Herfindahl-Hirschman Index (HHI) to investigate the trade dynamics between Turkey and Poland. The Herfindahl-Hirschman index is a form of export diversification indicator employed to evaluate the export portfolio between a country and its trading partners. The index was first introduced in the 1940s to measure skewness (Ergüzel et al., 2016) and subsequently adopted into mainstream economic and international trade studies (Cowling and Waterson, 1976). The general premise behind the export diversification thesis is to determine why countries diversify their exports and the potential benefits of such diversification initiatives on economic development (Samen, 2010; Ergüzel et al., 2016). Essentially, the Herfindahl-Hirschman Index is a measure of the degree concentration within a country or with its trading partners. The Herfindahl-Hirschman Index has two key components, namely the Product 
Concentration Index and the Market Concentration Index (World Bank, 2013). The Herfindahl-Hirschman Product Concentration Index measures the dispersion of trade value across an exporter's products, while the Herfindahl-Hirschman Market Concentration Index measures dispersion across an exporter's partners (World Bank, 2013). The Herfindahl-Hirschman index ranges between 0 and 1 where a value closer to 0 indicates a highly diversified export. This implies that a country with a perfectly diversified export portfolio will have an HHI close to zero, whereas a country which exports only one product will have a value of 1 (extremely concentrated product structure) (Parteka, 2013).

The mathematical definition of the Herfindahl-Hirschman index is expressed as:

$$
\frac{\sum_{k=1}^{n_{i}}\left(\frac{x_{i k}}{x_{i}}\right)^{2}-\frac{1}{n_{i}}}{1-\frac{1}{n_{1}}}
$$

Where $\boldsymbol{X}$ is the total value of exports from reporter $\boldsymbol{I}$ (Turkey and Poland), $\boldsymbol{x}$ is the value of exports of product $\boldsymbol{k}$ from country $\boldsymbol{i}$, and $\boldsymbol{n}$ is the number of products exported by country $\boldsymbol{i}$.

\section{DATA}

A key criterion relating to comparative studies deals with the availability of data. Therefore, to ensure minimal analytical inconsistencies, data for this study was accessed and retrieved from the World Bank's World Integrated Trade Solutions (WITS) platform, specifically the Trade Outcome Indicators, which is a gateway to trade statistics. The data which includes export, import and foreign direct investment in both countries covered the period between 1995 and 2015. This period coincides with crucial structural and institutional reforms in both countries. The Harmonized Commodity Description and Coding System popularly referred to as the Harmonized System (HS) specifically the two-digit level HS2 and all six-digit level HS6 were used in this study to measure the export diversification between Turkey and Poland. The HS Nomenclature is an internationally accepted method of classifying goods according to simply defined objective criteria and applications (World Customs Organization 2015).

\section{RESUlTS}

\section{Structural changes in import and export between Turkey and Poland}

As evident from table 1 and 2, imports into Poland and Turkey based on the HS2 nomenclature revealed significant differences and some level of similarities. For instance, both countries imported considerable quantities of food products, machinery, and electronics, as well as transport, wood, and footwear compared to other products, although the import of machinery and electronics, transportation and footwear were slightly higher in Poland compared to Turkey. Furthermore, both countries imported relatively fewer quantities of three particular products, namely fuels, stone and glass, and metals between 2011 and 2015 (figure 2). According to the World Bank (2013), the top five countries from which Poland imports goods are Germany (21.51\%), the Russian Federation (12.29\%), China (9.39\%), Italy (5.22\%), and the Netherlands (3.85\%). 
Table 1. Turkey's import product share in percentage from World between 2011 and 2015

\begin{tabular}{|l|r|r|r|r|r|r|r|}
\hline \multicolumn{1}{|c|}{ Product Name } & $\begin{array}{c}\text { Product } \\
\text { Code } \\
\text { (HS2) }\end{array}$ & 2011 & 2012 & 2013 & 2014 & 2015 & $2011-2015$ \\
\hline Animal & $01-05$ & 0.78 & 0.55 & 0.30 & 0.24 & 0.42 & -0.46 \\
\hline Vegetable & $06-15$ & 2.66 & 2.64 & 2.67 & 3.37 & 3.32 & 0.24 \\
\hline Food Products & $16-24$ & 1.16 & 1.41 & 1.52 & 1.57 & 1.74 & 0.50 \\
\hline Minerals & $25-27$ & 0.71 & 0.71 & 0.66 & 0.65 & 0.62 & -0.12 \\
\hline Fuels & $27-27$ & 8.19 & 8.73 & 8.04 & 8.31 & 6.96 & -0.15 \\
\hline Chemicals & $28-38$ & 8.08 & 7.60 & 7.52 & 8.27 & 8.53 & 0.05 \\
\hline Plastic or Rubber & $39-40$ & 6.62 & 6.58 & 6.74 & 7.03 & 7.15 & 0.08 \\
\hline Hides and Skin & $41-43$ & 0.54 & 0.54 & 0.53 & 0.48 & 0.39 & -0.27 \\
\hline Wood & $44-49$ & 2.21 & 2.25 & 2.22 & 2.33 & 2.51 & 0.13 \\
\hline Textile and Clothing & $50-63$ & 5.71 & 4.80 & 4.95 & 5.35 & 5.42 & -0.05 \\
\hline Footwear & $64-67$ & 0.42 & 0.41 & 0.45 & 0.45 & 0.45 & 0.07 \\
\hline Stone and Glass & $68-71$ & 3.62 & 4.28 & 7.20 & 4.20 & 2.90 & -0.19 \\
\hline Metals & $72-83$ & 13.71 & 13.30 & 12.38 & 12.49 & 12.3 & -0.10 \\
\hline $\begin{array}{l}\text { Machinery and } \\
\text { Electronics }\end{array}$ & $84-85$ & 18.24 & 18.00 & 19.03 & 19.00 & 20.84 & 0.14 \\
\hline Transportation & $86-89$ & 9.70 & 8.12 & 8.20 & 8.18 & 10.74 & 0.10 \\
\hline Miscellaneous & $90-99$ & 17.64 & 20.08 & 17.59 & 18.07 & 15.72 & -0.10 \\
\hline All Product & & 100.00 & 100.00 & 100.00 & 100.00 & 100.00 & \\
\hline
\end{tabular}

Source: authors' calculation from data obtained from WITS-UNSD Comtrade, World Development Indicators

Table 2. Poland's import product share in percentage from World between 2011 and 2015

\begin{tabular}{|l|r|r|r|r|r|r|r|}
\hline \multicolumn{1}{|c|}{ Product Name } & $\begin{array}{c}\text { Product } \\
\text { Code } \\
\text { (HS2) }\end{array}$ & 2011 & 2012 & 2013 & 2014 & 2015 & $2011-2015$ \\
\hline Animal & $01-05$ & 2.16 & 2.35 & 2.76 & 2.68 & 2.53 & 0.17 \\
\hline Vegetable & $06-15$ & 2.87 & 2.90 & 2.82 & 2.65 & 2.72 & -0.05 \\
\hline Food Products & $16-24$ & 3.31 & 3.61 & 3.62 & 3.61 & 3.81 & 0.15 \\
\hline Minerals & $25-27$ & 0.95 & 0.90 & 0.87 & 0.86 & 0.80 & -0.15 \\
\hline Fuels & $27-27$ & 12.82 & 13.67 & 11.64 & 10.8 & 7.52 & -0.41 \\
\hline Chemicals & $28-38$ & 9.73 & 9.54 & 9.82 & 9.92 & 9.64 & -0.00 \\
\hline Plastic or Rubber & $39-40$ & 7.73 & 7.52 & 7.70 & 7.62 & 7.46 & -0.03 \\
\hline Hides and Skin & $41-43$ & 0.56 & 0.54 & 0.59 & 0.66 & 0.67 & 0.19 \\
\hline Wood & $44-49$ & 3.52 & 3.36 & 3.43 & 3.51 & 3.64 & 0.03 \\
\hline Textile and Clothing & $50-63$ & 4.28 & 4.03 & 4.13 & 4.55 & 4.93 & 0.15 \\
\hline Footwear & $64-67$ & 0.62 & 0.64 & 0.70 & 0.79 & 0.89 & 0.43 \\
\hline Stone and Glass & $68-71$ & 1.41 & 1.30 & 1.26 & 1.26 & 1.30 & -0.07 \\
\hline Metals & $72-83$ & 10.90 & 10.42 & 10.32 & 10.45 & 10.34 & -0.05 \\
\hline $\begin{array}{l}\text { Machinery and } \\
\text { Electronics }\end{array}$ & $84-85$ & 22.03 & 22.22 & 23.18 & 23.82 & 26.11 & 0.18 \\
\hline Transportation & $86-89$ & 9.97 & 10.04 & 10.79 & 10.59 & 11.29 & 0.13 \\
\hline Miscellaneous & $90-99$ & 7.13 & 6.94 & 6.36 & 6.23 & 6.35 & -0.10 \\
\hline All Product & & 100.00 & 100.00 & 100.00 & 100.00 & 100.00 & \\
\hline
\end{tabular}

Source: authors' calculation from data obtained from WITS-UNSD Comtrade, World Development Indicators 
Figure 2. Percentage change in import from the World to Poland and Turkey (2011-2015)

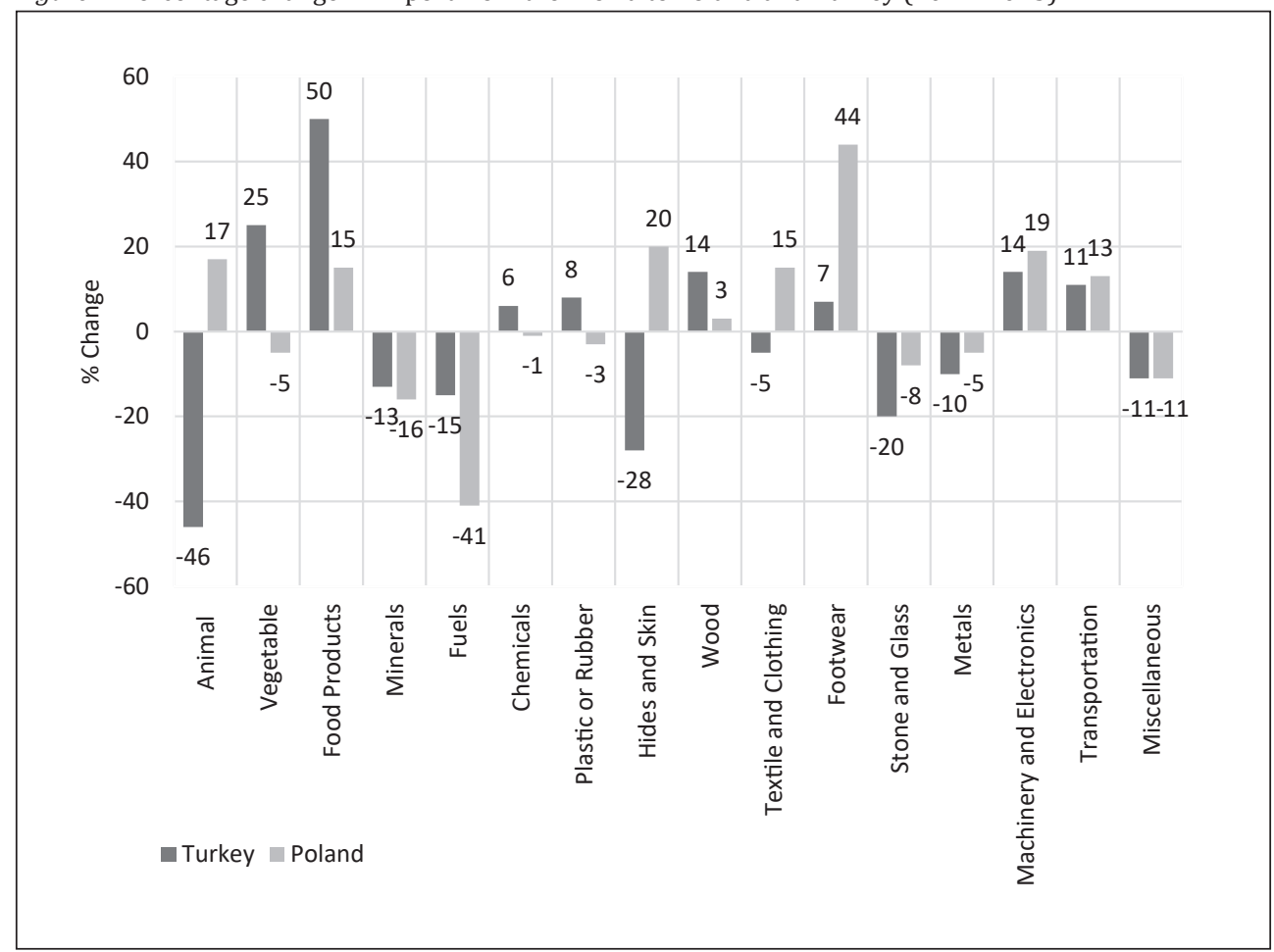

Source: authors' calculation from data obtained from WITS-UNSD Comtrade, World Development Indicators

More intriguing is the rate at which Poland in particular drastically reduced the import of fuel from $12.82 \%$ in 2011 to $7.52 \%$ as of 2015 (table 2). On the other hand, Turkey made significant progress towards energy sufficiency compared to Poland by importing less fuel.

As with the case of all major and emerging economies of which Turkey and Poland are not in the exemption, the share of export to GDP growth appears to be experiencing a slowdown. Export between Turkey and Poland has also been tremendously affected by the fall in export on the global market. With regards to Poland's export using HS2 product nomenclature, minerals, fuel, stone and glass, transportation and metals recorded a low export growth between 2011 and 2015 (figure 3), despite the fact that transportation (US\$ 28,458,260,57), machinery and electronics (US $\$ 49,046,774,96$ ) is a significant Polish export (see Table 3). Similarly, Turkey experienced a low export of hide and skins, mineral, as well as a relative decrease in the export of metals and fuel products (table 4). The share of exports of three particular products, namely footwear, food products, and animal experienced overall growth in both countries between 2011 and 2015. The Central Statistics Office of Poland also identified machinery and transport equipment, manufactured goods, miscellaneous manufactured articles, food and live animals, chemicals and related products as the core export $76.1 \%$ finds its way into the European Union (GUS, 2013). 
Table 3. Poland's export product share in percentage to the World (2011-2015)

\begin{tabular}{|l|r|r|r|r|r|r|r|}
\hline \multicolumn{1}{|c|}{ Product Name } & $\begin{array}{c}\text { Product } \\
\text { Code } \\
\text { (HS2) }\end{array}$ & 2011 & 2012 & 2013 & 2014 & 2015 & $2011-2015$ \\
\hline Animal & $01-05$ & 3.79 & 4.04 & 4.30 & 4.19 & 4.04 & 0.06 \\
\hline Vegetable & $06-15$ & 2.14 & 2.68 & 3.02 & 2.88 & 2.91 & 0.35 \\
\hline Food Products & $16-24$ & 5.17 & 5.60 & 5.88 & 5.98 & 6.22 & 0.20 \\
\hline Minerals & $25-27$ & 0.18 & 0.19 & 0.18 & 0.19 & 0.15 & -0.16 \\
\hline Fuels & $27-27$ & 4.90 & 5.00 & 4.70 & 4.14 & 3.31 & -0.32 \\
\hline Chemicals & $28-38$ & 6.77 & 6.94 & 6.93 & 7.01 & 6.61 & -0.02 \\
\hline Plastic or Rubber & $39-40$ & 7.06 & 7.03 & 7.18 & 6.93 & 6.89 & -0.02 \\
\hline Hides and Skin & $41-43$ & 0.39 & 0.38 & 0.47 & 0.54 & 0.58 & 0.48 \\
\hline Wood & $44-49$ & 4.95 & 5.04 & 5.10 & 5.13 & 5.13 & 0.03 \\
\hline Textile and Clothing & $50-63$ & 3.16 & 3.02 & 3.04 & 3.27 & 3.43 & 0.08 \\
\hline Footwear & $64-67$ & 0.40 & 0.47 & 0.53 & 0.54 & 0.60 & 0.50 \\
\hline Stone and Glass & $68-71$ & 2.85 & 3.06 & 2.59 & 2.54 & 2.46 & -0.13 \\
\hline Metals & $72-83$ & 11.85 & 11.70 & 10.87 & 10.58 & 9.84 & -0.16 \\
\hline $\begin{array}{l}\text { Machinery and } \\
\text { Electronics }\end{array}$ & $84-85$ & 23.60 & 23.77 & 23.70 & 24.65 & 25.22 & 0.068 \\
\hline Transportation & $86-89$ & 16.11 & 14.46 & 14.65 & 14.07 & 14.63 & -0.09 \\
\hline Miscellaneous & $90-99$ & 6.69 & 6.62 & 6.85 & 7.34 & 7.96 & 0.18 \\
\hline All Product & & 100.00 & 100.00 & 100.00 & 100.00 & 100.00 & \\
\hline
\end{tabular}

Source: authors' calculation from data obtained from WITS-UNSD Comtrade, World Development Indicators

Table 4. Turkey's export product share in percentage to the World (2011-2015)

\begin{tabular}{|l|r|r|r|r|r|r|r|}
\hline \multicolumn{1}{|c|}{ Product Name } & $\begin{array}{c}\text { Product } \\
\text { Code } \\
\text { (HS2) }\end{array}$ & 2011 & 2012 & 2013 & 2014 & 2015 & $2011-2015$ \\
\hline Animal & $01-05$ & 0.98 & 1.02 & 1.24 & 1.35 & 1.19 & 0.21 \\
\hline Vegetable & $06-15$ & 5.70 & 5.02 & 5.45 & 5.32 & 5.68 & -0.00 \\
\hline Food Products & $16-24$ & 4.03 & 3.98 & 4.52 & 4.76 & 4.82 & 0.19 \\
\hline Minerals & $25-27$ & 2.61 & 2.54 & 2.98 & 2.50 & 2.26 & -0.13 \\
\hline Fuels & $27-27$ & 4.75 & 4.90 & 4.27 & 3.73 & 2.99 & -0.37 \\
\hline Chemicals & $28-38$ & 3.06 & 3.07 & 3.24 & 3.32 & 3.44 & 0.12 \\
\hline Plastic or Rubber & $39-40$ & 5.32 & 4.88 & 5.33 & 5.52 & 5.16 & -0.03 \\
\hline Hides and Skin & $41-43$ & 0.61 & 0.55 & 0.59 & 0.57 & 0.45 & -0.26 \\
\hline Wood & $44-49$ & 1.63 & 1.60 & 1.85 & 1.95 & 1.93 & 0.18 \\
\hline Textile and Clothing & $50-63$ & 18.26 & 16.52 & 18.04 & 18.42 & 18.13 & -0.00 \\
\hline Footwear & $64-67$ & 0.35 & 0.38 & 0.50 & 0.48 & 0.49 & 0.40 \\
\hline Stone and Glass & $68-71$ & 4.98 & 12.76 & 6.83 & 7.13 & 10.04 & 1.01 \\
\hline Metals & $72-83$ & 15.95 & 14.43 & 13.81 & 13.20 & 11.56 & -0.27 \\
\hline $\begin{array}{l}\text { Machinery and } \\
\text { Electronics }\end{array}$ & $84-85$ & 15.15 & 14.02 & 14.84 & 14.77 & 14.33 & -0.05 \\
\hline Transportation & $86-89$ & 12.89 & 10.77 & 12.43 & 12.59 & 13.22 & 0.02 \\
\hline Miscellaneous & $90-99$ & 3.74 & 3.57 & 4.09 & 4.38 & 4.31 & 0.15 \\
\hline All Product & & 100.00 & 100.00 & 100.00 & 100.00 & 100.00 & \\
\hline
\end{tabular}

Source: authors' calculation from data obtained from WITS-UNSD Comtrade, World Development Indicators 
Figure 3. Percentage change in export from Poland and Turkey to the World (2011-2015)

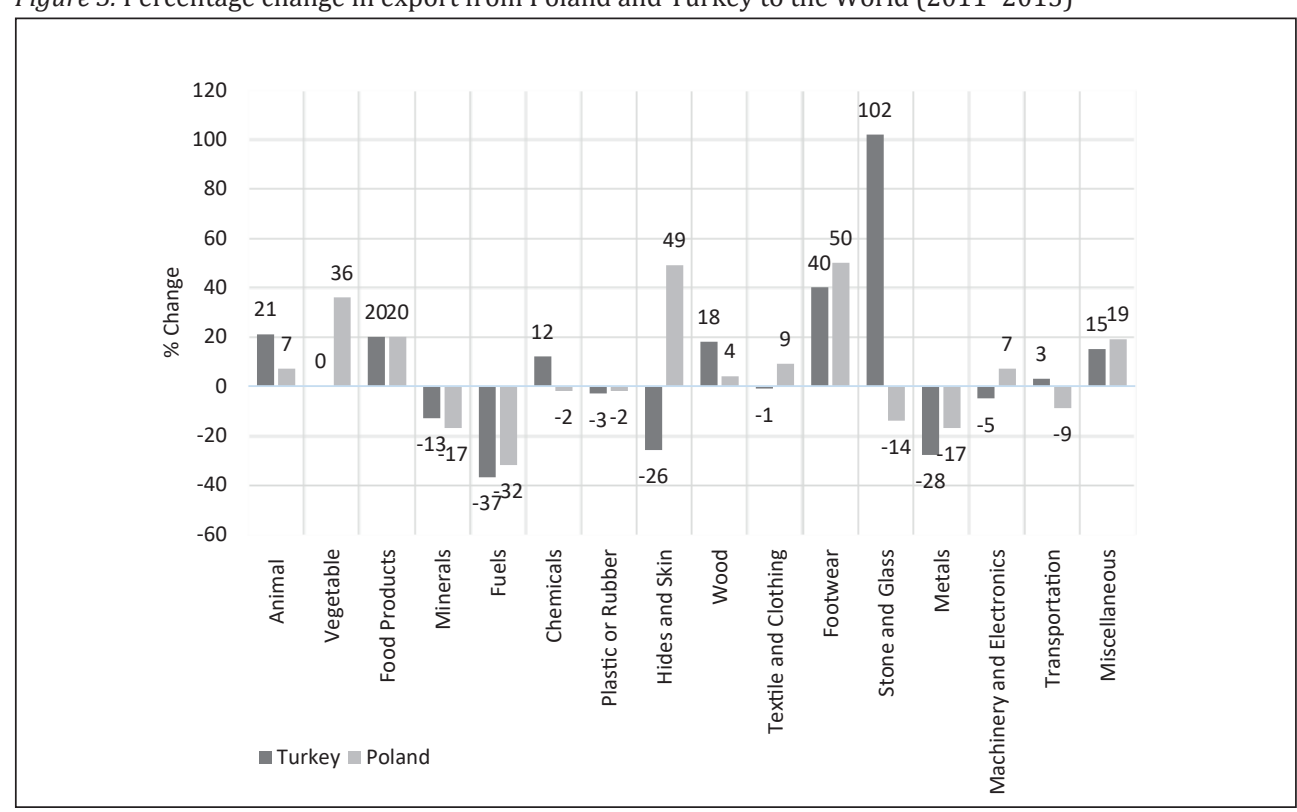

Source: authors' calculation from data obtained from WITS-UNSD Comtrade, World Development Indicators

\section{Trade diversification between Turkey and Poland}

Governments all over the world have prioritised export diversification (Ahmed and Sattar, 2012), although countries vary significantly on the implementation of diversification strategies. Figure 4. portrays the dynamics of export concentration between Turkey and selected trading partners from 1995 to 2015 based on the measure of all H6 product classifications. The results from the HHI measure indicates a relatively high export concentration between Turkey and three distinctive trading group: the World, the European Union, and Poland. Turkey's export to the world diversified during the period under study despite a slight decrease in concentration in 2005. A similar situation was experienced with export concentration to the EU which declined in 2005 and 2015. The general volatility in the world market, specifically global financial crisis, free trade agreements, diplomatic measures, and the economic shrinkage of European markets, at that time, has been implicated in the poor growth (Ergüzel et al., 2016). Turkey's export concentration to Poland, in particular, showed a very interesting dimension. For instance, in 1995, the export concentration was quite low based on an HHI value of 0.07 (figure 4). The results in 1995 implied that Turkey's export to Poland was less diversified. Subsequent years witnessed closer trade relations by way of Free Trade agreements negotiated particularly in 1999. Altan and Olcay (2016) also posited that the financial crisis that overwhelmed Turkey in 1994 and 2001 inspired the adoption of export-oriented policy programs which boosted export beyond post-crisis periods of 2001. Based on this and other influencing factors, Turkey's export to Poland experienced a higher concentration and diversification between 2000 and 2015 (figure 4). 
Figure 4. HHI export concentration between Turkey and Key Partners-HS6 digits

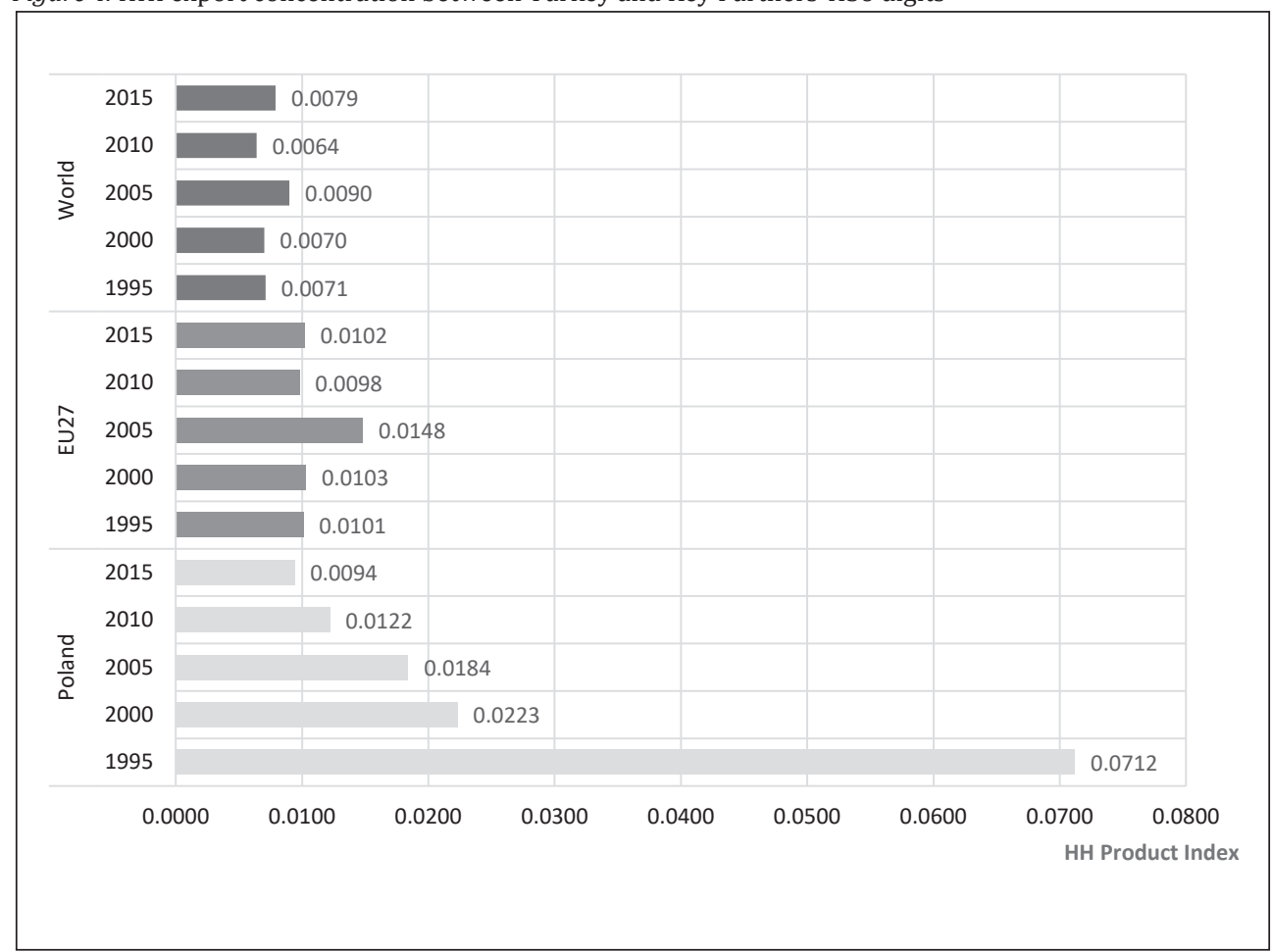

Source: WITS-UNSD Comtrade, World Development Indicators

The next stage of the analysis demonstrates whether there are inherent changes in the concentration of exports of goods from Turkey to Poland using HS2 and HS6 digits codes. According to Altan and Olcay (2016) Turkey has successfully expanded its export of almost all product varieties making the country one of the most diversified emerging markets and trading partner. The export concentration from Turkey to Poland in 1995 was generally low, although the export of hides and skins was highly concentrated as compared to other traded products (Table 5). Transport and chemicals products which were the least traded products in 1995, experienced a boost in export between 2010 and 2015. The share of exports to GDP from Turkey to Poland of products such as fuels and vegetables has consistently declined between 1995 and 2015. For instance, the HHI value for vegetables increased from 0.1851 in 1995 to 0.4432 in 2015, implying a reduction in the export concentration of vegetables. A similar situation applies to the export concentration of fuels from Turkey to Poland (Table 5). However, a general evaluation of export concentration using all HS6 digit codes from Turkey to Poland shows a high HHI values implying a rise in export concentration. The findings of the HHI procedure does not show any major structural changes in export concentration from Turkey to Poland, although a relatively uniform export structure is evident. According to Klinger and Lederman (2006), a more uniform export share of existing products implies an increasing diversification. A study by Ergüzel et al. (2016) with respect to HS2 product classifications also found no significant structural changes and patterns in Turkish exports. 
Table 5. HHI export concentration from Turkey to Poland-HS2 and HS6 digits

\begin{tabular}{|l|c|c|c|c|c|c|}
\cline { 3 - 7 } \multicolumn{2}{c}{} & \multicolumn{5}{c|}{ Product Concentration Index } \\
\hline Product Name & HS2 Code & 1995 & 2000 & 2005 & 2010 & 2015 \\
\hline Animal & $01-05$ & 0.00 & - & 0.37 & 0.33 & 0.35 \\
\hline Fegetable & $06-15$ & 0.18 & 0.10 & 0.27 & 0.17 & 0.44 \\
\hline Minerals & $16-24$ & 0.31 & 0.34 & 0.23 & 0.15 & 0.20 \\
\hline Fuels & $25-26$ & 0.28 & 0.46 & 0.63 & 0.39 & 0.20 \\
\hline Chemicals & $27-27$ & - & - & 0.57 & 0.87 & 0.60 \\
\hline Plastic or Rubber & $28-38$ & 0.53 & 0.84 & 0.32 & 0.06 & 0.06 \\
\hline Hides and Skin & $39-40$ & 0.32 & 0.09 & 0.09 & 0.06 & 0.03 \\
\hline Wood & $41-43$ & 0.08 & 0.25 & 0.16 & 0.12 & 0.31 \\
\hline Textile and Clothing & $44-49$ & 0.35 & 0.20 & 0.17 & 0.09 & 0.08 \\
\hline Footwear & $50-63$ & 0.10 & 0.05 & 0.02 & 0.02 & 0.02 \\
\hline Stone and Glass & $64-67$ & 0.19 & 0.43 & 0.15 & 0.20 & 0.11 \\
\hline Metals & $68-71$ & 0.31 & 0.18 & 0.30 & 0.17 & 0.22 \\
\hline Machinery and Electronics & $72-83$ & 0.27 & 0.15 & 0.12 & 0.05 & 0.04 \\
\hline Transport & $84-85$ & 0.16 & 0.30 & 0.21 & 0.09 & 0.03 \\
\hline Miscellaneous & $86-89$ & 0.80 & 0.28 & 0.10 & 0.10 & 0.08 \\
\hline AllSubHeading & $90-99$ & 0.20 & 0.20 & 0.05 & 0.04 & 0.03 \\
\hline
\end{tabular}

Source: authors' calculation from data obtained from WITS-UNSD Comtrade, World Development Indicators

Table 6. HHI export concentration from Poland to Turkey-HS2 and HS6 digits

\begin{tabular}{|l|c|c|c|c|c|c|}
\cline { 3 - 7 } \multicolumn{2}{c}{} & \multicolumn{5}{c|}{ Product Concentration Index } \\
\hline Product Name & HS2 Code & 1995 & 2000 & 2005 & 2010 & 2015 \\
\hline Vegetable & $01-05$ & - & 0.16 & 0.38 & 0.67 & 0.81 \\
\hline Food Products & $06-15$ & 0.22 & - & 0.07 & 0.22 & 0.06 \\
\hline Minerals & $16-24$ & - & 0.46 & 0.22 & 0.29 & 0.21 \\
\hline Fuels & $25-27$ & - & - & - & - & 0.31 \\
\hline Chemicals & $27-27$ & - & 0.70 & 0.42 & 0.42 & 0.30 \\
\hline Plastic or Rubber & $28-38$ & 0.34 & 0.13 & 0.32 & 0.23 & 0.09 \\
\hline Hides and Skin & $39-40$ & - & 0.10 & 0.07 & 0.08 & 0.06 \\
\hline Wood & $41-43$ & - & - & - & - & 0.66 \\
\hline Textile and Clothing & $44-49$ & 0.15 & 0.24 & 0.12 & 0.09 & 0.10 \\
\hline Footwear & $50-63$ & 0.19 & 0.17 & 0.38 & 0.23 & 0.05 \\
\hline Stone and Glass & $64-67$ & - & - & - & - & 0.14 \\
\hline Metals & $68-71$ & 0.26 & 0.05 & 0.10 & 0.12 & 0.07 \\
\hline Machinery and Electronics & $84-85$ & 0.39 & 0.08 & 0.45 & 0.09 & 0.14 \\
\hline Transport & $86-89$ & 0.09 & 0.21 & 0.23 & 0.08 & 0.16 \\
\hline Miscellaneous & $90-99$ & 0.09 & 0.31 & 0.15 & 0.08 & 0.05 \\
\hline AllSubHeading & All HS6 & 0.05 & 0.11 & 0.19 & 0.17 & 0.04 \\
\hline
\end{tabular}

Source: authors' calculation from data obtained from WITS-UNSD Comtrade, World Development Indicators 
Regarding Polish export concentration to Turkey based on HS2 and all HS6 product nomenclature (table 6), concentration decreased compared to Turkey's export concentration to Poland. The possible explanation for this trend may be partly due to the fact that the European Union serves as the major market for Polish exports, thereby accounting for the relatively less diversified portfolio of Polish export to Turkey. For instance, Poland had no prior export of certain products such as minerals, hides and skin, and footwear to Turkey until 2015. Products such as metals, stone and glass, plastic or rubber experienced a relatively high export concentration from Poland to Turkey based on their HHI values. The export concentration of animal products, specifically hides and skin was extremely low. Data from the Central Statistical Office of Poland also recorded a considerable decline in the export of food products (66\%) from Poland to Turkey in 2013, despite the fact that Polish export of food products grew at 14\% in 2013 to major markets in the British Isles (EUR 1.5 billion), Russia (EUR 1.2 billion), the Czech Republic (EUR 1.2 billion), France (EUR 1.2 billion), Italy (EUR 1 billion), and the Netherlands (also EUR 1 billion). This was due to import regulations on new beef by the Turkish government. According to Balcer (2015), Polish exports to Turkey has consistently decreased since 2011.

\section{CONCLUSION}

What are the implications of the current dynamics of trade on future partnerships? It is imperative that Turkey and Poland consolidate their existing partnership by removing trade barriers that may hinder stronger economic relations and cooperation. Essentially, further progress requires expanded agreements irrespective of pre-existing bilateral partnerships between Turkey and the EU in general. Furthermore, reforms are needed in both countries to closely align production structures necessary for greater and more sustained trade partnership. In the end, the analysis indicates a very promising trading partnership in key sectors of their respective economies, as well as increased diversification of new products. The general structure of exports concentration shows the dominance of manufactured products which are quintessential for economic growth and development. A detailed outlook of product groups based on export shows a uniform and, in some cases, slight structural changes in export concentration between the two countries. To a significant extent, the structural dynamics provides an insight into how trade has evolved between Turkey and Poland, as well as the complex processes that propel trade specifically export between the two economies. Clearly, the application of concentration indexes such as the HHI does not provide an overall outlook of the dynamics of trade between countries. Future research should focus on the qualitative dimensions, specifically, sector by sector analysis, as well as the role of key industrial players with regards to promoting or impeding trade cooperation between the two countries. Furthermore, another key area of consideration includes the nature of sophistication of trade between Turkey and Poland.

\section{REFERENCES}

Ahmed,S. Sattar, Z. (2012). Reducing Vulnerabilityin ExportPerformance: The Export Diversification Challenge in Bangladesh, International Growth Centre. London, United Kingdom: London School of Economics. 
Altan, A, Olcay, Y.Ç. (2016). The role of the extensive margin in export of Turkey: A comparative Analysis. Central Bank Review, 16, 59-64

Arip, M.A., Yee, L. S., and Abdul Karim B. (2010). Export Diversification and Economic Growth in Malaysia. MPRA Paper, 20588, 1-10.

Ayrancı, E. (2009). Türkiye'nin Ekonomik Açıdan Küreselleșmesinin Yoğunlaşma Vasıtasıyla Ölçülmesi ve Konu Hakkında Bir Araștırma. Anadolu Bil MYO Dergisi, 4(16): 50-64.

Balcer, A. (2015). A Polish-Romanian-Turkish Triangle and the Black Sea Region - A New Driving Force of Regional Integration? Neighborhood Policy Paper.

Belke, A. (2005). Turkey in transition to EU membership: Pros and cons of integrating a dynamic economy. Perceptions, 10, 53-63.

Carrere, C., Strauss-Kahn, V., Cadot, O. (2011). Export diversification: What's behind the hump? The Review of Economics and Statistics, 93(2): 590-605.

Central Statistical Office of Poland (GUS) (2013). Yearbook of foreign trade statistics 2013. Warsaw: GUS.

Cowling, K., Waterson, M. (1976). Price-cost margins and market structure. Econ New Ser, 43(171): 267-274.

Demianova, V. (2008). EU Foreign Direct Investment in Croatia and Turkey. Eurostat Statistics in Focus. European Union.

Emirhan, P.N. (2008). How Sophisticated are Poland's and Turkey's Exports? International Journal of Emerging and Transition Economies, 1(2), 257-274.

Ergüzel, O.S., Tunahan, H., Esen, S. (2016). Measuring the Globalization of Cities from the New Regionalism Perspective. SpringerPlus, 5, 1536

Erkan, B. (2014). Product and Market Diversification in Turkey's Foreign Trade. International Journal of Advances in Management and Economics, 3(1), 1-15.

Erlat, G., Sahin, B. (1998). Export Diversification in Turkey over Time. METU Studies in Development, 25, 47-60.

Gökalp, M.F., Yıldırım, A. (2004), "Effects of the Customs Union on Turkey and the EU Relations", Avrupa Birliği Sürecinde Türkiye, Siyasal Ekonomik ve Toplumsal Dönüşüm, Sorunlar ve Tartışmalar, (edt: T.Uzun, S.Özen), Seçkin Yayınevi, Ankara, 263-288.

Gros, D., Selçuki, C. (2013). The Changing Structure of Turkey's Trade and Industrial Competitiveness: Implications for the EU. Global Turkey in Europe working paper.

Gurgul, H., Lach, Ł. (2010). International Trade and Economic Growth in the Polish Economy. Operations Research and Decisions, 20(3-4), 5-29

Hesse, H. (2008). Export Diversification and Economic Growth. The World Bank Commission on Growth and Development, 21, 1-25.

Inançlı, S., Akal, M. (2013). Export and Import Products Groups' Shares of Turkey with CEE Countries after theirs Accessions to EU and before. Asian Economic and Financial Review, 3(11), 1419-1438.

Kirişçi, K., Kaptanoğlu, N. (2011). 'The politics of trade and Turkish foreign policy'. Middle Eastern Studies, 47(5).

Klinger, B., Lederman, D. (2006). Diversification, Innovation, and Imitation inside the Global Technological Frontier. World Bank Policy Research Working Paper, 3872.

Krueger, A.O., Aktan, O.H. (1992). Swimming Against the Tide: Turkish Trade Reforms in the 1980s. International Center for Economic Growth.

Maćkowiak, H. (2011). The Goods Structure of Trade between Polish Regions and the European Union. Bulletin of Geography. Socio-economic Series, 16, 57-74.

Mierzwa, J. (2015). Polish-Turkish relations in the $19^{\text {th }}$ and $20^{\text {th }}$ centuries: The struggle for independence and modernization. Journal of Economics and Management, 20(A), 6-21.

Ministry of Foreign Affairs (2011). Relations between Turkey and Poland. Republic of Turkey, Ankara.

Naude, W., Rossouw, R. (2008). Export Diversification and Specialization in South Africa: Extent and Impact. World Institute for Development Economic Research, 93(1-36).

Öniş, Z., Bayram, I.E. (2010). “Temporary Star or Emerging Tiger? Turkey's Economic Performance in a Global Setting". In T. Çetin, F. Yilmaz (eds.). Understanding the Process of Economic Change in Turkey. Nova Science Publishers, Inc.

Öniş, Z., Rubin, B. (eds.) (2003). The Turkish Economy in Crisis. London: Frank Cass. 
Pamuk, Ș. (2007). Economic Change in Twentieth Century Turkey: Is the Glass More than Half Full? American University of Paris. Working Paper, 41.

Parteka, A. (2013). The Evolving Structure of Polish Exports (1994-2010). Diversification of Products and Trade Partners. Bank i Kredyt, 5, 435-466.

Saif, I., Barakat, N. (2005). Competition, Competition Policy and Economic Efficiency in the MENA Region-Jordan's Country Report. IDRC Final Report. 1-69.

Samen, S. (2010). The primer on export diversification: key concepts, theoretical underpinnings and empirical evidence. Growth and Crisis Unit. World Bank Institute.

Secer, A. (2008). An Investigation on Turkish Hazelnut Export Concentration. Journal of Applied Sciences Research, 4(11), 1557-1560.

Seymen, D. (2009). Gümrük Birliği, Türkiye'nin Avrupa Birliği ile Ticaretinde Ülke Yoğunlaşmasını Değiștirdi mi? Süleyman Demirel Üniversitesi İktisadi ve İdari Bilimler Fakültesi Dergisi, 14(1), 199-220.

Seymen, D., Bilici, Ö. (2009). Has Customs Union Changed the Country Concentration of Trade between Turkey and the European Union? European Trade Study Group 10th Annual Conference, ETSG 2009, Rome, 1-14

Şimşek, N., Seymen, D., Utkulu, U. (2007). Turkey's Competitiveness in the EU Market: A Comparison of Different Trade Measures, European Trade Study Group, 9th Annual Conference, Athens.

ThinkTank Dossier (2014). 600 th years of Polish-Turkish Diplomatic Relations. Available from: mttp.pl/pobieranie/DOSSIER_TURCJA.pdf.

Togan, S. (1994). Foreign Trade Regime and Trade Liberalization in Turkey during the 1980s. Aldershot: Avebury, Ashgate Publishing Ltd.

Topaktaș, H. (2014). Ottoman-Polish Relations from the Turkish Perspective: Written, Unwritten and Remembered. Herito, 14, 50-61.

TurkStat (2016). Foreign Trade Statistics. Ankara: Turkish Statistical Institute.

Ustaoğlu, M., Y ıldız, B. (2011). Information Technology's Effect on Turkey's Foreign Trade: An Investigation for the Last Decade. 7th International Strategic Management Conference. Paris.

Voinea, L. (2002). Advancing at its own speed: A trade approach on Romania's convergence to EU. Romanian J. European Affairs, 2(3), 56-71.

Wilhelms, C. (1967). Export diversification in Latin America. Intereconomics, 2, 46-48.

World Bank (2007). Export Diversification in Egypt, Lebanon, Jordan, Morocco and Tunisia. Social and Economic Development Sector Unit Middle East and North Africa Region, 2, 1-91.

World Bank (2014). Evaluation of the EU-Turkey Customs Union. Report No. 85830-TR. Washington DC: The World Bank Group.

World Bank (2016). The World Bank in Poland: A Country Snapshot. Washington DC: The World Bank Group.

World Bank (2016). The World Bank in Turkey: A Country Snapshot. Washington DC: The World Bank Group.

World Bank World Integrated Trade Solutions (2013). Online trade outcomes indicators - User's Manual Solutions. Version 1.0

Word Customs Organization (2015). Retrieved from www.Wcoomd.Org

World Trade Organization (2000). Trade policy reviews of Poland, 2000. Retrieved from http:// www.wto.org/english/tratop_e/tpr_e/tp136_e.htm

Xin, X., Liu, J. (2008). Geographic Concentration and China's Agricultural Export Instability. The World Economy, 31(2), 275-285.

Yilmaz, B. (2003). Turkey's Competitiveness in the European Union: A Comparison with Five Candidate Countries - Bulgaria, the Czech Republic, Hungary, Poland, Romania - and the EU15. Ezoneplus Working Paper, 12.

Michael Gameli Dziwornu, Ph.D. student in Urban Studies at the University of Milan-Bicocca. He holds a BA and an MA in Geography from the University of Ghana and the Suleyman Demirel University, respectively. His research interests include urban political economy and migration. 


\section{Address:}

University of Milan-Bicocca

Department of Sociology and Social Research

Piazza dell'Ateneo Nuovo, 1-20126 Milan, Italy

e-mail: dzimike.md@gmail.com

Tomasz Rachwal, Ph.D., head of the Department of Entrepreneurship and Spatial Management of Institute of Geography of the Pedagogical University of Cracow, Rector's Proxy for Entrepreneurship, member of the Senate of the Pedagogical University of Cracow, Deputy Chair of the Industrial Geography Commission of the Polish Geographical Society, member of the editorial board of several journals, author of textbooks for geography and entrepreneurship. His research interests focus primarily on the issue of change of spatial and branch structures of industry, the determinants for the development of various branches of industrial activity, export diversification of Polish industrial products and the role of manufacturing, selected branches of services and entrepreneurship in local and regional development, as well as on geographical and entrepreneurship education.

\section{Address:}

Pedagogical University of Cracow

Institute of Geography

Department of Entrepreneurship and Spatial Management

ul. Podchorążych 2, 30-084 Kraków, Poland

e-mail: Tomasz.Rachwal@up.krakow.pl 